\title{
The influence of riparian evapotranspiration on stream hydrology and nitrogen retention in a subhumid Mediterranean catchment
}

\author{
Anna Lupon ${ }^{1}$, Susana Bernal ${ }^{1,2}$, Sílvia Poblador ${ }^{1}$, Eugènia Martí ${ }^{2}$, and Francesc Sabater ${ }^{1,3}$ \\ ${ }^{1}$ Department d'Ecologia, Universitat de Barcelona, Av. Diagonal 643, 08028 Barcelona, Spain \\ ${ }^{2}$ Integrative Freshwater Ecology Group, Center for Advanced Studies of Blanes (CEAB-CSIC), Accés a la Cala Sant \\ Francesc 14, 17300 Blanes, Spain \\ ${ }^{3}$ CREAF, Campus de Bellaterra (UAB) Edifici C, 08193 Cerdanyola del Vallès, Spain \\ Correspondence to: Anna Lupon (alupon@ub.edu)
}

Received: 3 February 2016 - Published in Hydrol. Earth Syst. Sci. Discuss.: 8 March 2016

Revised: 25 August 2016 - Accepted: 26 August 2016 - Published: 14 September 2016

\begin{abstract}
Riparian evapotranspiration (ET) can influence stream hydrology at catchment scale by promoting the net loss of water from the stream towards the riparian zone (i.e., stream hydrological retention). However, the consequences of stream hydrological retention on nitrogen dynamics are not well understood. To fill this gap of knowledge, we investigated changes in riparian ET, stream discharge, and nutrient chemistry in two contiguous reaches (headwater and valley) with contrasted riparian forest size in a small forested Mediterranean catchment. Additionally, riparian groundwater level $\left(h_{\mathrm{gw}}\right)$ was measured at the valley reach. The temporal pattern of riparian ET was similar between reaches, and was positively correlated with $h_{\mathrm{gw}}(\rho=0.60)$ and negatively correlated with net riparian groundwater inputs $(\rho<-0.55)$. During the vegetative period, stream hydrological retention occurred mostly at the valley reach (59\% of the time), and was accompanied by in-stream nitrate release and ammonium uptake. During the dormant period, when the stream gained water from riparian groundwater, results showed small influences of riparian ET on stream hydrology and nitrogen concentrations. Despite being a small component of annual water budgets (4.5\%), our results highlight that riparian ET drives stream and groundwater hydrology in this Mediterranean catchment and, furthermore, question the potential of the riparian zone as a natural filter of nitrogen loads.
\end{abstract}

\section{Introduction}

The study of riparian zones has been of growing interest during the last decades because they can reduce the pervasive effects of excessive anthropogenic nitrogen $(\mathrm{N})$ inputs in forested, agricultural, and urban ecosystems across the globe (Hill, 1996; Pert et al., 2010). Since they can affect both the timing and magnitude of $\mathrm{N}$ delivery to downstream ecosystems, riparian zones are currently considered hot spots of $\mathrm{N}$ removal within catchments (McClain et al., 2003; Vidon et al., 2010). The high capacity of riparian zones to reduce terrestrial $\mathrm{N}$ inputs stems from the biogeochemical conditions at their unique interface location between upland and streams, which favors ammonium $\left(\mathrm{NH}_{4}^{+}\right)$and nitrate $\left(\mathrm{NO}_{3}^{-}\right)$biological uptake from shallow groundwater via plant assimilation and microbial denitrification (Clément et al., 2003; Vidon et al., 2010).

The capacity of riparian zones to diminish inorganic $\mathrm{N}$ loads critically relies on the hydrological connectivity between upland, riparian, and stream ecosystems because it directly influences water flow paths, and thereby whether groundwater $\mathrm{N}$ interacts with organic-rich soils (Mayer et al., 2007; Pinay et al., 2000). During wet conditions, the $\mathrm{N}$ retention in riparian zones is high because continuous upland groundwater inputs and the rising water table in flat riparian areas can promote the contact of groundwater with shallow riparian soils (Ranalli and Macalady, 2010; Vidon and Hill, 2004). However, little is known about the efficiency of riparian zones to diminish $\mathrm{N}$ inputs during dry conditions, when the hydrological connectivity between uplands and ri- 
parian zones tends to decrease at the valley bottom of catchments (Covino and McGlynn, 2007; Detty and McGuire, 2010; Jencso et al., 2009; Ocampo et al., 2006). Low or zero water inputs from uplands can drop the riparian groundwater level far below the organic-rich and rhizosphere soil layers and, consequently, diminish the capacity of riparian zones for removing groundwater N (Burt et al., 2002; Hefting et al., 2004). Conversely, hydrological disconnection between uplands and riparian zones can favor the lateral movement of water from the stream toward the riparian aquifer (defined here as stream hydrological retention), which can enhance denitrification and biological uptake of stream nitrate at the stream-riparian edge (Duval and Hill, 2007; Martí et al., 1997; Rassam et al., 2006; Schade et al., 2005).

The riparian groundwater level and the hydrological exchange between the stream and riparian groundwater can be directly influenced by the activity of riparian trees, which can consume high amounts of water during the vegetative period. Riparian evapotranspiration (ET) can drive diel fluctuations of stream discharge and seasonal patterns of the riparian groundwater table and soil moisture (Brooks et al., 2009; Burt et al., 2002; Gribovszki et al., 2010). Thus, riparian trees could affect the strength, location, and duration of the predominant flow path, and consequently, influence the capacity of riparian zones to reduce $\mathrm{N}$ not only from upland groundwater inputs, but also from stream water. In this line of thought, previous studies have reported decreases in stream $\mathrm{N}$ concentration along losing stream reaches attributed to $\mathrm{N}$ uptake at the stream-riparian edge (Bernal and Sabater, 2012; Dent et al., 2007; Rassam et al., 2006). Yet, there has been little research focused on the influence of riparian ET on upland-riparian-stream hydrological exchange and its potential to promote variations in stream $\mathrm{N}$ concentrations and fluxes.

This study aims to investigate the influence of riparian ET on stream hydrological retention, and its consequences on stream $\mathrm{N}$ concentrations in a small forested Mediterranean catchment. To do so, we compared riparian tree ET between a headwater reach with limited riparian forest and a contiguous valley reach with a well-developed riparian forest. First, we expected higher riparian ET, and thus, higher stream hydrological retention at the valley reach, especially during the vegetative period. Second, we expected that differences in stream $\mathrm{N}$ concentration between the headwater and valley reach will reflect differences in riparian $\mathrm{N}$ cycling coupled to the dominant direction of water flow between the riparian zone and the stream. Based on longitudinal changes observed in semiarid streams (Bernal and Sabater, 2012; Dent et al., 2007), we expected decreases in $\mathrm{N}$ concentration along the two reaches, but especially at the valley reach because of higher stream hydrological retention. The results of this study contribute to our understanding of the interaction between riparian ET and fluxes of water and nutrients at the stream-riparian edge. This knowledge could have implications for water resource management, as well as for antici-

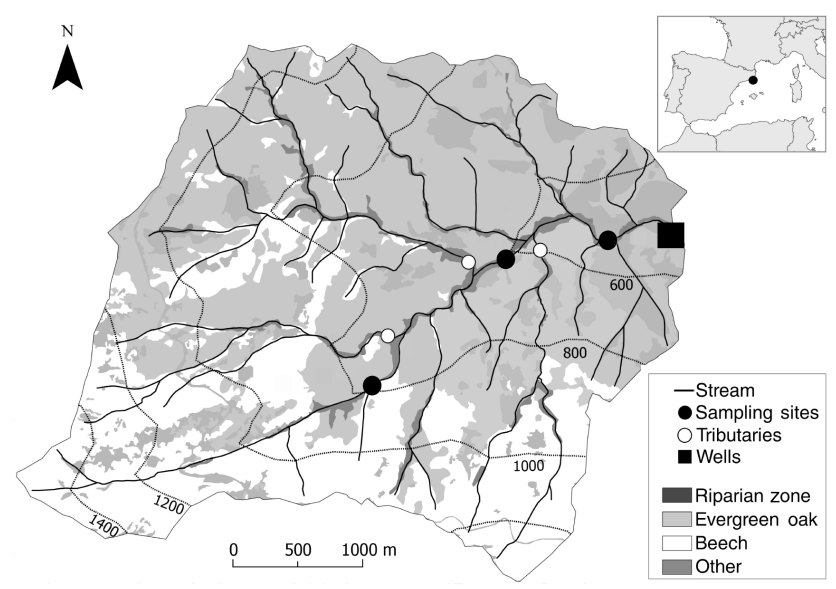

Figure 1. Map of the Font del Regàs catchment (Montseny Natural Park, northeastern Spain). The location of the three sampling sites (black circles), tributaries (white circles), and the riparian plot where tree transpiration and groundwater level were measured (black square) are shown. The headwater reach is comprised between the up- and midstream sampling sites, while the valley reach is comprised between the mid- and downstream sampling sites.

pating how riparian zones and stream-water chemistry could respond to decreases in water availability induced by climate change.

\section{Study site}

The Font del Regàs catchment is located in the Montseny Natural Park, northeastern Spain $\left(41^{\circ} 50^{\prime} \mathrm{N}, 2^{\circ} 30^{\prime} \mathrm{E}\right)$. The climate is subhumid Mediterranean, with mild winters, wet springs, and dry summers. Annual precipitation is $925 \pm 151 \mathrm{~mm}$, with $<1 \%$ of annual precipitation falling as snow. Mean annual temperature averages $12.1 \pm 2.5^{\circ} \mathrm{C}$ (mean \pm SD, period 1940-2000, Catalan Metereologic Service). Atmospheric inorganic $\mathrm{N}$ deposition ranges from 15 to $30 \mathrm{~kg} \mathrm{ha}^{-1} \mathrm{yr}^{-1}$ and does not show any temporal trend (period 1983-2007; Àvila and Rodà, 2012).

The catchment area is $14.2 \mathrm{~km}^{2}$ and its altitude ranges from 500 to $1500 \mathrm{~m}$ a.s.l. (above the sea level) (Fig. 1). The catchment is dominated by biotitic granite and it has steep slopes (28\%) (Institut Cartogràtic de Catalunya, 2010). Evergreen oak (Quercus ilex) and European beech (Fagus sylvatica) forests cover $54 \%$ and $38 \%$ of the catchment, respectively (Fig. 1). Upland soils ( $\mathrm{pH} \sim 6$ ) are sandy, with a $3 \mathrm{~cm}$ deep $\mathrm{O}$ horizon followed by a 5 to $15 \mathrm{~cm}$ deep A horizon. There is no snowpack in hillslope areas and upland soils are generally $>0{ }^{\circ} \mathrm{C}$. The riparian forest covers the $6 \%$ of the catchment area and it is almost flat (slope perpendicular to stream $<10 \%$ ). Riparian width increases from 6 to $28 \mathrm{~m}$ along the catchment and the total basal area of riparian trees increases by 12 -fold. Note that by total basal area we are referring to the sum of individual tree basal area as defined 
later in the text. Black alder (Alnus glutinosa), black locust (Robinea pseudoacacia), sycamore (Platanus $x$ hispanica), European ash (Fraxinus excelsior), and black poplar (Populus nigra) are the most abundant tree species in the riparian forest. Riparian soils $(\mathrm{pH} \sim 7)$ are sandy loam, with a $5 \mathrm{~cm}$ deep organic layer followed by a $30 \mathrm{~cm}$ deep A horizon.

For this study, we selected two contiguous stream reaches with contrasting riparian forest (i.e., the headwater and valley reach) (Fig. 1). The headwater reach (750-550 $\mathrm{m}$ a.s.1.) is $1760 \mathrm{~m}$ long and drains $6.74 \mathrm{~km}^{2}$ (Table 1). The reach is flanked by a 5-15 $\mathrm{m}$ wide riparian forest that covers $\sim 5 \%$ of the drainage area. A. glutinosa, F. excelsior, and P. nigra represent 51,26 , and $23 \%$ of the total basal area, respectively. The valley reach $(550-500 \mathrm{~m}$ a.s.1.) is $1160 \mathrm{~m}$ long and drains an additional area of $4.42 \mathrm{~km}^{2}$ (i.e., total catchment area at this reach is $11.16 \mathrm{~km}^{2}$ ). The reach is flanked by a $10-25 \mathrm{~m}$ wide riparian forest that covers $\sim 10 \%$ of the drainage area. A. glutinosa, F. excelsior, P. nigra, and $R$. pseudoacacia represents $53,27,11$, and $9 \%$ of the total basal area, respectively. The two stream reaches show well-preserved channel morphology, with a riffle-run structure and low slopes $(<5 \%)$ along the reaches. The streambed is mainly composed by rock $(\sim 30 \%)$, cobbles $(\sim 25 \%)$, and gravel $(\sim 15 \%)$ at the headwater reach, whereas rock ( $\sim 25 \%)$, cobbles $(\sim 30 \%)$, and sand $(\sim 30 \%)$ are the dominant substrates at the valley reach. The stream channel is, on average, 2 and $3 \mathrm{~m}$ wide for the headwater and the valley reach, respectively. During the study period, riparian groundwater $(<1.5 \mathrm{~m}$ from the stream channel) flowed well below the soil surface in the two reaches $(0.5 \pm 0.1 \mathrm{~m}$; averaged from 14 wells, 7 by reach; $n=82$ ) (Bernal et al., 2015).

\section{Materials and methods}

\subsection{Field sampling and chemical water analysis}

To characterize the riparian forest, we inventoried 14 riparian forest plots of $30 \mathrm{~m}$ long $\times$ riparian width $(5-20 \mathrm{~m})$ (seven plots by reach, $\sim 5 \%$ of the riparian area). In each plot, we identified each individual tree at species level and measured its diameter breast height $(\mathrm{DBH}$; in $\mathrm{cm}$ ) and its basal area $\left(\mathrm{BA}=\pi(\mathrm{DBH} / 2)^{2}\right.$, in $\left.\mathrm{cm}^{2}\right)$. For each tree species $i$, we calculated the area-specific $\mathrm{BA}\left(\mathrm{BA}_{\mathrm{sp}, i}\right.$; in $\mathrm{m}^{2}$ of $\mathrm{BA}$ per $\mathrm{km}^{2}$ of riparian area) by dividing the total $\mathrm{BA}$ for a given species by the total area of the inventoried riparian plots, either for the headwater $\left(0.23 \mathrm{~km}^{2}\right)$ or valley $\left(0.21 \mathrm{~km}^{2}\right)$ reach.

During 2 consecutive water years (from September 2010 to August 2012), we monitored three stream sampling sites (up-, mid-, and downstream sites), which constituted the top and the bottom of the headwater and valley reaches. Streamwater level was recorded at $15 \mathrm{~min}$ intervals at each sampling site with a water pressure transducer (HOBO U20-001$04)$. Fortnightly, stream discharge $\left(Q\right.$; in $\left.\mathrm{L} \mathrm{s}^{-1}\right)$ was measured using the "slug" chloride addition technique (Gordon
Table 1. Reach length, catchment drainage area, percentage of riparian area, width of the riparian zone, and total basal area of riparian trees for the headwater and valley reaches.

\begin{tabular}{|c|c|c|c|c|c|}
\hline & \multicolumn{3}{|c|}{ Reach characteristics } & \multicolumn{2}{|c|}{$\begin{array}{l}\text { Riparian zone } \\
\text { characteristics }\end{array}$} \\
\hline & $\begin{array}{l}\text { Length } \\
\text { (m) }\end{array}$ & $\begin{array}{c}\text { Drainage } \\
\text { area } \\
\left(\mathrm{km}^{2}\right)\end{array}$ & $\begin{array}{c}\text { Area } \\
(\%)\end{array}$ & $\begin{array}{c}\text { Mean } \\
\text { width } \\
(\mathrm{m})\end{array}$ & $\begin{array}{c}\text { Total } \\
\text { basal } \\
\text { area } \\
\left(\mathrm{m}^{2} \mathrm{BA}\right)\end{array}$ \\
\hline Headwater & 1760 & 6.74 & 4.9 & 12 & 822 \\
\hline Valley & 1161 & 4.42 & 9.9 & 19 & 1354 \\
\hline
\end{tabular}

et al., 1992). We used the regression between discharge and stream-water level measurements to infer $Q$ values at $15 \mathrm{~min}$ intervals during the study period $(n=57,60$, and 61 for up-, mid- and downstream sites, respectively; in all cases: $R^{2}>0.97$; Fig. S1 in the Supplement). In order to compare stream discharge among the three sites, we calculated area-specific stream discharge $\left(Q^{\prime} ;\right.$ in $\left.\mathrm{mm} \mathrm{day}^{-1}\right)$ by dividing $Q$ by drainage area. Riparian groundwater level $\left(h_{\mathrm{gw}}\right.$; in cm b.s.s. (below soil surface) was recorded at $15 \mathrm{~min}$ intervals with a water pressure transducer (HOBO U20-001$04)$ in a $1.8 \mathrm{~m}$ long PVC (polyvinyl chloride) well $(3 \mathrm{~cm} \varnothing)$ placed $\sim 3 \mathrm{~m}$ from the stream channel edge at the downstream site (Fig. 1).

Stream-water samples were collected daily (at noon) from each sampling site with an auto-sampler (Teledyne Isco Model 1612) and taken to the laboratory every 10 days. Autosamplers were installed about $1 \mathrm{~m}$ below ground to keep water samples fresh and prevent biogeochemical transformations (Fig. S2). From August 2010 to December 2011, discharge and water chemistry was measured every 2 months at the three permanent tributaries discharging to Font del Regàs stream (Fig. 1). We used pre-acid-washed polyethylene bottles to collect water samples after triple rinsing them with stream water. All water samples were filtered (Whatman GF/F, $0.7 \mu$ m pore $\varnothing$ ) and kept cold $\left(<4^{\circ} \mathrm{C}\right)$ until laboratory analysis ( $<24 \mathrm{~h}$ after collection). Water samples were analyzed for dissolved inorganic $\mathrm{N}$ (DIN; $\mathrm{NO}_{3}^{-}$ and $\mathrm{NH}_{4}^{+}$) and chloride $\left(\mathrm{Cl}^{-}\right)$, which was used as hydrological tracer (Kirchner et al., 2001). $\mathrm{Cl}^{-}$was analyzed by ionic chromatography (Compact IC-761, Methrom). $\mathrm{NO}_{3}^{-}$ was analyzed by the cadmium reduction method (Keeney and Nelson, 1982) using a Technicon Autoanalyzer (Technicon, 1976). $\mathrm{NH}_{4}^{+}$was manually analyzed by the salicilate/nitropruside method (Baethgen and Alley, 1989) using a spectrophotometer (PharmaSpec UV-1700 SHIMADZU).

\subsection{Riparian evapotranspiration}

From September 2010 to August 2012, we calculated diel variations in stream discharge at the up-, mid-, and downstream sites $\left(Q_{\text {lost }}\right.$, in $\mathrm{m}^{3}$ day $\left.^{-1}\right)$ by subtracting daily $Q$ to 
the stream discharge obtained by linearly interpolating maxima $Q$ (measured between 00:00 and 03:00 LT) between two consecutive days. We used only stream discharge during base-flow conditions (i.e., changes in $Q<10 \%$ in $24 \mathrm{~h}$ ) to avoid any confounding effect associated with storm events. During the vegetative period, we attributed $Q_{\text {lost }}$ to water withdrawal by riparian tree roots from either the riparian aquifer or directly from the stream channel (Cadol et al., 2012). Given that there was no snowpack in the study catchment, $Q_{\text {lost }}$ during the dormant period was attributed to water withdrawal by riparian understory vegetation (Roberts, 1983) and/or by upland evergreen trees (Savé et al., 1999). Furthermore, we estimated riparian ET along each reach as the difference in $Q_{\text {lost }}$ measured at the bottom and at the top of the reach and by assuming that $Q_{\text {lost }}$ measured at each particular site integrated the riparian ET upstream from that point. Riparian ET ( $\Delta Q_{\text {lost }}$, in $\mathrm{m}^{3} \mathrm{~m}^{-1}$ day $\left.^{-1}\right)$ was weighted by stream length for comparison purposes. For the valley reach, we compared $\Delta Q_{\text {lost }}$ values with diel variations in $h_{\mathrm{gw}}$ to explore the influence of riparian ET on the riparian groundwater level.

To explore the relation between diel cycles in stream discharge and the activity of riparian trees, we compared $\Delta Q_{\text {lost }}$ with an independent estimate of riparian transpiration based on mean monthly sap-flow measurements of the dominant riparian trees ( 8 individuals of $A$. glutinosa, 5 individuals of F. excelsior, 5 individuals of $P$. nigra, and 12 individuals of $R$. pseudoacacia). Sap flow was measured using constant thermal dissipation sensors (Granier, 1985). Each sensor consisted of two probes (10-20 mm long) inserted in the north side of the trunk at breast height $10 \mathrm{~cm}$ apart. The upper probe was heated at a constant temperature. The thermal difference between probes was scanned at $10 \mathrm{~s}$ intervals and recorded as a $15 \mathrm{~min}$ average with a data logger (CR1000, Campbell Inc.). Then, thermal differences were related to sap flux density (in $\mathrm{dm}^{3}$ of water per $\mathrm{m}^{2}$ of BA and minute) following the original calibration of Granier (1985). More details can be found in Nadal-Sala et al. (2013).

For each reach, we calculated the transpiration of the riparian tree community $\left(T_{\text {rip }}\right.$, in $\mathrm{m}^{3} \mathrm{~m}^{-1}$ day $\left.^{-1}\right)$ with

$$
T_{\text {rip }}=\left(\sum_{i=1}^{n} T_{i} \times \mathrm{BA}_{\mathrm{sp}, i}\right) \times A / x,
$$

where $T_{i}$ is monthly mean daily transpiration (in $\mathrm{dm}^{3}$ of water per $\mathrm{m}^{2}$ of $\mathrm{BA}$ and day) and $\mathrm{BA}_{\mathrm{sp}, i}$ is the area-specific basal area (in $\mathrm{m}^{2} \mathrm{BA} \mathrm{km}^{-2}$ ) of each tree species $i, A$ is the riparian area (in $\mathrm{km}^{2}$ ), and $x$ is the reach length (in $\mathrm{m}$ ). Values of mean monthly $T$ were recorded at the valley of the catchment from January to August 2012 (Nadal-Sala et al., 2013).

\subsection{Mass balance calculations}

\subsubsection{Net riparian groundwater inputs to stream}

To examine the temporal and spatial pattern of stream hydrological retention, we measured the hydrological exchange between riparian groundwater and stream-water bodies at reach scale. The contribution of mean daily net riparian groundwater inputs to stream discharge $\left(Q_{\mathrm{gw}}\right)$ was estimated with

$Q_{\mathrm{gw}}=Q_{\mathrm{bot}}-Q_{\mathrm{top}}-Q_{\text {trib }}$,

where $Q_{\text {top }}$ and $Q_{\text {bot }}$ are mean daily discharge measured at the top and at the bottom of the reach, respectively, and $Q_{\text {trib }}$ is mean daily discharge at the permanent tributaries (all in $\mathrm{L} \mathrm{s}^{-1}$ ). For the headwater reach, $Q_{\text {top }}$ and $Q_{\text {bot }}$ were the discharge at the up- and midstream sites, respectively; while we used the discharge at the mid- and downstream sites for the valley reach. For each stream site, mean daily discharge was the average of $Q$ for each day. To estimate mean daily discharge at each tributary, we used the best-fit model (logarithmic model) between $Q$ measured at each tributary and at the upstream site within the same day (for each of the three tributaries: $R^{2}>0.97, n=11, p<0.001$; Fig. S3). Values of $Q_{\mathrm{gw}}>0$ indicate the movement of water from the riparian zone to the stream (i.e., net gaining stream), whereas values of $Q_{\mathrm{gw}}<0$ indicate a net loss of water from the stream towards the riparian zone. Therefore, $Q_{\mathrm{gw}}<0$ was used as an indicator of stream hydrological retention (Covino et al., 2010).

\subsubsection{Chemical signature of riparian groundwater and stream water}

We used a mass balance approach to investigate whether changes in stream-water $\mathrm{Cl}^{-}, \mathrm{NO}_{3}^{-}$, and $\mathrm{NH}_{4}^{+}$concentrations along the valley reach could be explained by hydrological mixing between riparian groundwater and stream water. The mass balance was focused at the valley reach, where water and $\mathrm{N}$ retention were expected to be the highest. Only discharge and solute concentrations during base-flow conditions were used for the mass balance approach. For each day, we calculated a predicted concentration for the downstream site with the following mass balance:

$Q_{\mathrm{bot}} \times C_{\mathrm{bot}}=Q_{\mathrm{top}} \times C_{\mathrm{top}}+Q_{\mathrm{gw}} \times C_{\mathrm{gw}}+Q_{\text {trib }} \times C_{\text {trib }}$,

where $Q_{\text {top }}, Q_{\text {bot }}, Q_{\text {trib }}$, and $Q_{\text {gw }}$ are as in Eq. (2) (all in $\left.\mathrm{L} \mathrm{s}^{-1}\right) . C_{\text {top }}$ and $C_{\text {bot }}$ are daily solute concentrations measured at the top and at the bottom of the reach, respectively (in $\mathrm{mg} \mathrm{L}^{-1}$ ). $C_{\text {trib }}$ is daily solute concentration at the tributaries (in $\mathrm{mg} \mathrm{L}^{-1}$ ), which was estimated by fitting the bestfit model (logarithmic model) between solute concentration measured at each tributary and at the upstream site within the same day (for each of the three tributaries and for the three solute: $R^{2}>0.78$; in all cases: $n=11, p<0.001$; Fig. S3). 
Although this may be a rough estimation of solute concentrations at the tributaries, it was a useful procedure for inferring riparian groundwater chemistry at daily time steps. Finally, $C_{\mathrm{gw}}$ is daily solute concentration in riparian groundwater (in $\mathrm{mg} \mathrm{L}^{-1}$ ). For periods of $Q_{\mathrm{gw}}<0$, we considered that $C_{\mathrm{gw}}$ equaled $C_{\text {top }}$. For periods of $Q_{\mathrm{gw}}>0$, we assumed similar riparian groundwater chemistry between the headwater and valley reaches. In this case, $C_{\mathrm{gw}}$ at the headwater reach was inferred from Eq. (3) by assuming that there was no biological reactivity within the stream channel. The predicted $C_{\mathrm{gw}}$ showed a good match with the concentrations measured at seven wells installed along the headwater reach $(<2 \mathrm{~m}$ from the stream), with median $C_{\mathrm{gw}}$ differing $<5,7$, and $10 \%$ for $\mathrm{Cl}^{-}, \mathrm{NO}_{3}^{-}$, and $\mathrm{NH}_{4}^{+}$, respectively (Bernal et al., 2015) (Table S1 in the Supplement).

For each day, we calculated the ratio between observed and predicted solute concentrations (Obs: Pred ratio). For $\mathrm{Cl}^{-}$(hydrological tracer), we expected Obs:Pred ratios close to 1 if there are no additional water sources contributing to stream discharge at the valley reach. For $\mathrm{NO}_{3}^{-}$and $\mathrm{NH}_{4}^{+}$, Obs: Pred $<1$ and $Q_{\mathrm{gw}}<0$ was interpreted as instream biological $\mathrm{N}$ retention via assimilatory uptake (for $\mathrm{NO}_{3}^{-}$and $\mathrm{NH}_{4}^{+}$), nitrification (for $\mathrm{NH}_{4}^{+}$), and/or denitrification (for $\mathrm{NO}_{3}^{-}$). We interpreted Obs : Pred $>1$ and $Q_{\mathrm{gw}}<0$ as either in-stream mineralization (for $\mathrm{NH}_{4}^{+}$) or nitrification (for $\mathrm{NO}_{3}^{-}$). For $Q_{\mathrm{gw}}>0$ (net gaining stream), Obs : Pred $\neq 1$ was interpreted as differences in riparian groundwater nutrient concentration between the headwater and the valley reaches. We used the relative difference between measured and predicted $C_{\mathrm{gw}}$ at the headwater reach as a threshold to determine when observed and predicted concentrations differed significantly from each other $( \pm 1.05, \pm 1.07$, and \pm 1.1 for $\mathrm{Cl}^{-}, \mathrm{NO}_{3}^{-}$, and $\mathrm{NH}_{4}^{+}$concentrations, respectively).

\subsection{Statistical analysis}

To investigate the influence of riparian ET on stream discharge and stream-water chemistry, we split the data set into vegetative and dormant periods. We considered that the vegetative period was compressed between the onset (April) and offset (October) of riparian tree evapotranspiration (NadalSala et al., 2013).

For each reach, we investigated differences in $Q^{\prime}, Q_{\mathrm{gw}}$, mean daily $h_{\mathrm{gw}}$, and stream solute concentrations between the two periods with a Wilcoxon rank sum test (Zar, 2010). For each period, the occurrence of stream hydrological retention was calculated by counting the number of days with $Q_{\mathrm{gw}}<0$. For each reach, we further explored the relationship between $T_{\text {rip }}, \Delta Q_{\text {lost }}$, and $Q_{\mathrm{gw}}$ with a Spearman correlation. A Spearman correlation was also used to analyze the relationship between $\Delta Q_{\text {lost }}$ and mean daily $h_{\mathrm{gw}}$ at the valley reach.

To explore whether stream hydrological retention influenced stream $\mathrm{NO}_{3}^{-}$and $\mathrm{NH}_{4}^{+}$concentrations at the valley reach, we examined the relationship between $Q_{\mathrm{gw}}$ and
Obs: Pred ratios measured at the downstream site with Spearman correlations. For each solute, we further compared the Obs : Pred ratio between days with $Q_{\mathrm{gw}}>0$ and $Q_{\mathrm{gw}}<0$ with a Wilcoxon rank sum test (Zar, 2010).

All the statistical analyses were carried out with the R 2.15.1 statistical software (R Core Team, 2012). We chose non-parametric statistical tests because the residuals of both stream discharge and solute concentrations were not normally distributed (Shapiro test, $p<0.05$ ). In all cases, differences were considered statistically significant when $p<0.01$.

\section{Results}

\subsection{Seasonal and diel patterns of stream discharge and whole-reach riparian ET}

During the study period, median annual $Q$ was $15.9,53.9$, and $62.4 \mathrm{~L} \mathrm{~s}^{-1}$ at the up-, mid-, and downstream sites, respectively. The three sites showed the same seasonal pattern, characterized by a strong decline in $Q$ during the vegetative period (Fig. 2a). As expressed by catchment area, median annual $Q^{\prime}$ was $0.65,0.53$, and $0.41 \mathrm{~mm} \mathrm{day}^{-1}$ at the up-, mid-, and downstream sites, respectively. In all sites, $Q^{\prime}$ was significantly higher during the dormant than during the vegetative period (Wilcoxon test, $p<0.01$ ).

Diel variations in stream discharge occurred during the whole year, with maxima in early morning (03:00-06:00 LT) and minima in early afternoon (14:00-17:00 LT). During the dormant period, diel discharge variations were relatively small at the three sites $\left(Q_{\text {lost }}<2 \%\right.$ of mean daily $Q$ ). Values of $Q_{\text {lost }}$ increased during the vegetative period and showed a marked longitudinal pattern, median values being 36,219 , and $340 \mathrm{~m}^{3}$ day $^{-1}$ at the up-, mid-, and downstream sites, respectively. At the three sites, $Q_{\text {lost }}$ increased from April to June, peaked in summer (July-August), and then decreased until November. In the summer peak, $Q_{\text {lost }}$ accounted for the 7,15 , and $19 \%$ of mean daily $Q$ at the up-, mid-, and downstream sites, respectively. This seasonal pattern of $Q_{\text {lost }}$ was consistent for the 2 studied water years.

During the vegetative period, riparian ET was lower at the headwater than at the valley reach as indicated by $\Delta Q_{\text {lost }}\left(0.12\right.$ vs. $0.17 \mathrm{~m}^{3} \mathrm{~m}^{-1}$ day $\left.^{-1}\right)$ and $T_{\text {rip }}(0.31$ vs. $0.49 \mathrm{~m}^{3} \mathrm{~m}^{-1}$ day $\left.^{-1}\right)$. There was a strong and positive relationship between $T_{\text {rip }}$ and $\Delta Q_{\text {lost }}$ for both the headwater and valley reach (Fig. 3a). Both $T_{\text {rip }}$ and $\Delta Q_{\text {lost }}$ peaked in summer (July-August) and showed minima in winter (January-March). At the valley reach, there was a positive relationship between $\Delta Q_{\text {lost }}$ and diel variations in $h_{\mathrm{gw}}$ (Spearman coefficient $[\rho]=0.58, p<0.001, n=277$ ). 

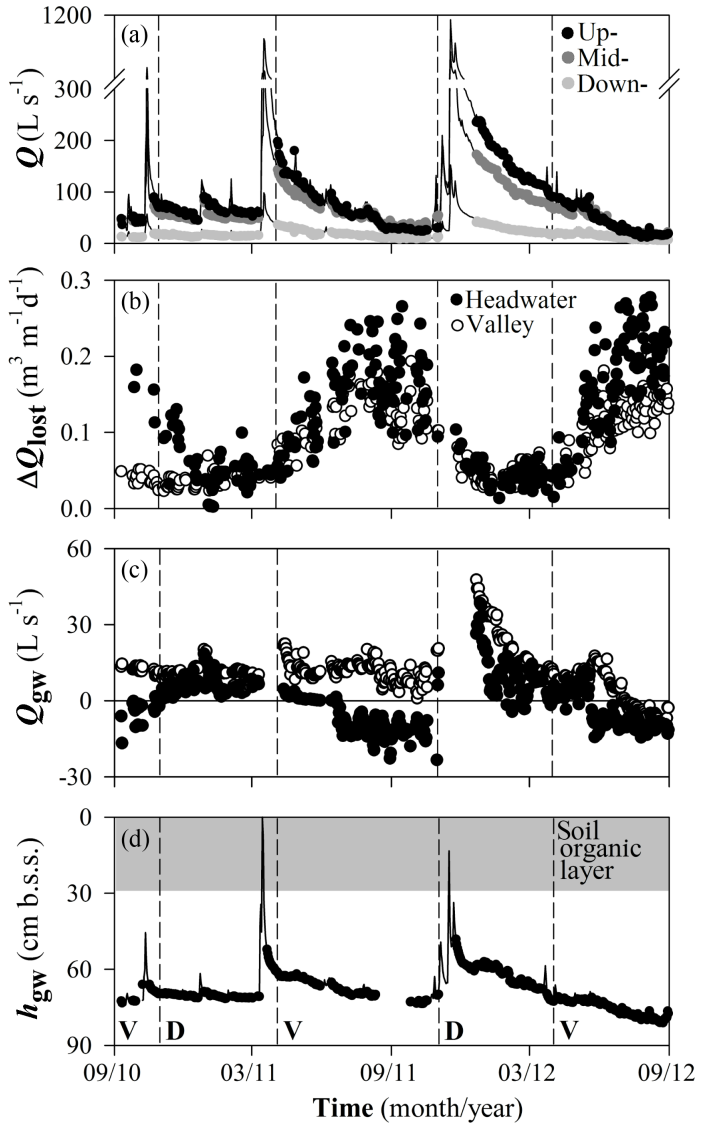

Figure 2. Temporal pattern for the period 2010-2012 of (a) stream discharge $(Q)$ at the up- (light gray), mid- (dark gray), and downstream (black) sites, (b) riparian evapotranspiration $\left(\Delta Q_{\text {lost }}\right)$ estimated as the difference in the diel variation in discharge between the top and the bottom of the headwater (white) and valley (black) reaches, (c) daily net riparian groundwater inputs $\left(Q_{\mathrm{gw}}\right)$ for the headwater (white) and valley (black) reaches, and (d) groundwater table fluctuation $\left(h_{\mathrm{gw}}\right)$ at the valley bottom. In $(\mathbf{c})$, the $Q_{\mathrm{gw}}=0$ line is shown as a reference of nil net riparian to stream-water inputs; $Q_{\mathrm{gw}}>0$ and $<0$ indicates when the stream reach was net gaining and net losing water, respectively. In (d), the mean soil depth of the A horizon is indicated. V: vegetative period, D: dormant period.

\subsection{Net riparian groundwater inputs and groundwater table elevation}

Median annual $Q_{\mathrm{gw}}$ was positive at the headwater reach $\left(11.2 \mathrm{~L} \mathrm{~s}^{-1}\right)$, but negative at the valley reach $\left(-0.5 \mathrm{~L} \mathrm{~s}^{-1}\right)$. The two reaches showed lower $Q_{\mathrm{gw}}$ values during the vegetative period compared to the dormant period, though differences were larger at the valley reach (Table 2, Fig. 2c). The two reaches showed a negative correlation between $Q_{\mathrm{gw}}$ and $\Delta Q_{\text {lost }}$ (headwater: $\rho=-0.57, p<0.001, n=273$; valley: $\rho=-0.79, p<0.001, n=286$ ) (Fig. 3b).

Stream hydrological retention $\left(Q_{\mathrm{gw}}<0\right)$ was more frequent at the valley reach compared to the headwater reach ( $27 \%$ vs. $4 \%$ of the time on an annual basis). During the
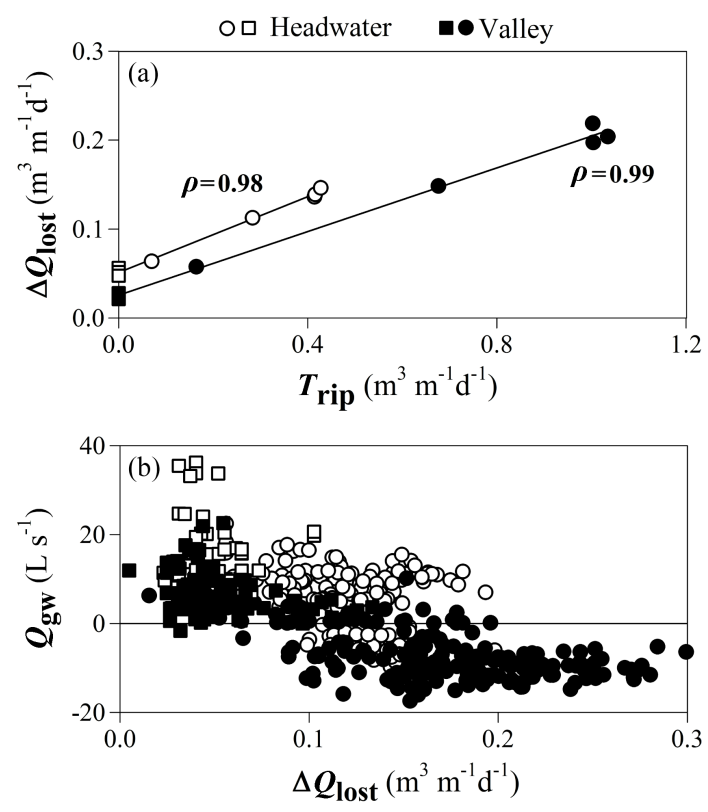

Figure 3. Relationship between (a) the monthly mean of daily riparian transpiration estimated from sap-flow data $\left(T_{\text {rip }}\right)$ and riparian evapotranspiration estimated as the difference in diel discharge variation between the top and the bottom of each stream reach $\left(\Delta Q_{\text {lost }}\right)$, and (b) $\Delta Q_{\text {lost }}$ and daily net riparian groundwater inputs ( $\left.Q_{\mathrm{gw}}\right)$ for the headwater (white) and valley (black) reaches. Data are shown separately for the vegetative (circles) and dormant (squares) period. The Spearman coefficients are indicated in (a) (in both cases: $p<0.01, n=8)$. In (b), the $Q_{\mathrm{gw}}=0$ line is shown as a reference of nil net riparian to stream-water inputs; $Q_{\mathrm{gw}}>0$ and $<0$ indicates when the stream reach was net gaining and net losing water, respectively.

vegetative period, $Q_{\mathrm{gw}}<0$ occurred from May to September (59\% of the time) at the valley reach, while it occurred only in July and August at the headwater reach (15\% of the time). During the dormant period, days with $Q_{\mathrm{gw}}<0$ were infrequent ( $<3 \%$ of the time) for the valley reach and nil for the headwater reach.

At the downstream site, median annual $h_{\mathrm{gw}}$ was $70 \mathrm{~cm}$ b.s.s. and showed higher values (i.e., lower water table levels) during the vegetative period compared to the dormant period (Fig. 2d, Table 2). There was a moderate positive correlation between mean daily $h_{\mathrm{gw}}$ and $\Delta Q_{\text {lost }}(\rho=0.60$, $p<0.001, n=277)$.

\subsection{Stream solute concentrations}

Stream $\mathrm{Cl}^{-}$concentration was lower at the upstream than at the mid- and downstream sites for both the vegetative and dormant periods (Table 3). The upstream site showed no differences in stream $\mathrm{Cl}^{-}$concentration between the two periods, while the mid- and downstream sites showed lower $\mathrm{Cl}^{-}$ concentration during the dormant than during the vegetative period (Table 3). The highest stream $\mathrm{NO}_{3}^{-}$concentration was 
Table 2. Net groundwater inputs to stream discharge $\left(Q_{\mathrm{gw}}\right)$, number of days with stream hydrological retention $\left(Q_{\mathrm{gw}}<0\right)$ and groundwater depth $\left(h_{\mathrm{gw}}\right)$ for the vegetative and dormant period, respectively. The number of cases is shown in parentheses for each group. For $Q_{\mathrm{gw}}$ and $h_{\mathrm{gw}}$, data are shown as median \pm interquartile range [25th, 75th], and the asterisks indicate statistically significant differences between the two periods (Wilcoxon rank sum test, ${ }^{*} p<0.01$ ).

\begin{tabular}{llll}
\hline & & Vegetative & Dormant \\
\hline \multirow{2}{*}{$Q_{\mathrm{gw}}\left(\mathrm{L} \mathrm{s}^{-1}\right)$} & Headwater & $10.4[6.9,13.2](373)$ & $11.8[10.4,15.7](237)^{*}$ \\
& Valley & $-5.3[-10.1,2.1](373)$ & $6.0[3.6,9.0](237)^{*}$ \\
\hline \multirow{2}{*}{$Q_{\mathrm{gw}}<0$ (days) } & Headwater & $57(373)$ & $0(237)$ \\
& Valley & $219(373)$ & $6(237)$ \\
\hline \multirow{2}{*}{$h_{\mathrm{gw}}(\mathrm{cm}$ b.s.s. $)$} & Headwater & - & - \\
& Valley & $72.3[68.7,76.2](256)$ & $69.6[65.3,70.7](189)^{*}$ \\
\hline
\end{tabular}

observed at the upstream site and the lowest at the midstream site (Table 3). Stream $\mathrm{NO}_{3}^{-}$concentration was higher during the dormant than during the vegetative period at the up- and midstream sites, while no seasonal pattern was observed at the downstream site (Table 3). Stream $\mathrm{NH}_{4}^{+}$concentration was higher at the upstream than at the downstream site. The three sites showed higher stream $\mathrm{NH}_{4}^{+}$concentration during the vegetative than during the dormant period (Table 3 ).

\subsection{Comparison between observed and predicted stream solute concentrations at the downstream site}

During the study period, there was a good match between observed stream $\mathrm{Cl}^{-}$concentrations at the downstream site and those predicted by hydrological mixing as indicated by Obs: Pred ratios $\sim 1$ (Fig. 4a). For $\mathrm{NO}_{3}^{-}$, Obs: Pred ratios were close to 1 during the dormant period, while increased up to 1.95 during the vegetative period (Fig. 4b). For $\mathrm{NH}_{4}^{+}$, Obs: Pred ratios were higher during the dormant period $(\sim 1.15)$ than during the vegetative period (from 0.29 to 0.87 ) (Fig. 4c).

The relationship between Obs: Pred ratios and $Q_{\mathrm{gw}}$ was nil for $\mathrm{Cl}^{-}(\rho=0.2, p>0.05)$, negative for $\mathrm{NO}_{3}^{-}$, and positive for $\mathrm{NH}_{4}^{+}$(Fig. 5). For $\mathrm{NO}_{3}^{-}$, Obs: Pred ratios were significantly higher for $Q_{\mathrm{gw}}<0$ than for $Q_{\mathrm{gw}}>0$, while the opposite pattern was observed for $\mathrm{NH}_{4}^{+}$(for the two solutes: Wilcoxon test, $Z>Z_{0.05}, p<0.01$ ).

\section{Discussion}

\subsection{Influence of riparian ET on stream and riparian groundwater hydrology}

Our results revealed that riparian ET can influence stream and riparian groundwater hydrology, though its relevance varies depending on the timescale considered. On a subdaily basis, the strong relationship between $T_{\text {rip }}$, diel variation in $h_{\mathrm{gw}}$, and $\Delta Q_{\text {lost }}$ suggests that riparian vegetation drives diel fluctuations in stream discharge likely by taking up water from the riparian aquifer (Cadol et al., 2012;
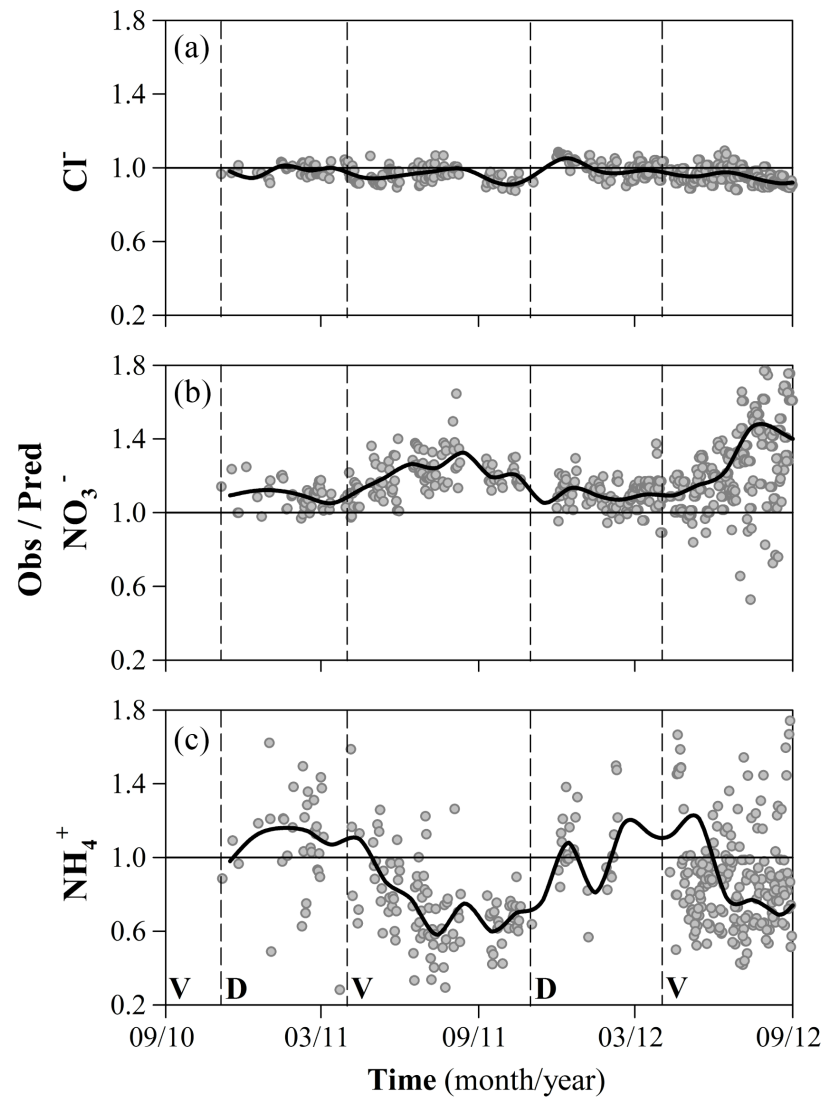

Figure 4. Temporal pattern of the ratio between observed stream solute concentrations at the bottom of the valley reach (downstream site) and those predicted from hydrological mixing for (a) chloride, (b) nitrate, and (c) ammonium during the period 2010-2012. Bold lines indicate the running median (the half-window is 7 days). The Obs : Pred $=1$ line is indicated as a reference. V: vegetative period, D: dormant period.

Gribovszki et al., 2010; Lundquist and Cayan, 2002). However, the fact that $\Delta Q_{\text {lost }}$ values were lower than those of $T_{\text {rip }}$ suggest that riparian trees fed also on soil water. This result concurs with previous studies showing that riparian tree 
Table 3. Median and interquartile range [25th, 75th] of stream solute concentrations at each sampling site for the vegetative and dormant periods. The number of cases is shown in parentheses for each group. The asterisks indicate statistically significant differences between the two periods (Wilcoxon rank sum test, ${ }^{*} p<0.01$ ).

\begin{tabular}{llll}
\hline & & Vegetative & Dormant \\
\hline \multirow{3}{*}{$\mathrm{Cl}^{-}\left(\mathrm{mg} \mathrm{L}^{-1}\right)$} & Upstream site & $6.1[5.7,6.5](281)$ & $6.0[5.8,6.2](176)$ \\
& Midstream site & $8.0[7.7,8.4](333)$ & $7.4[7.2,8.6](220)^{*}$ \\
& Downstream site & $8.3[7.9,8.8](302)$ & $7.7[7.5,7.8](184)^{*}$ \\
\hline \multirow{2}{*}{$\mathrm{NO}_{3}^{-}\left(\mu \mathrm{g} \mathrm{N} \mathrm{L}^{-1}\right)$} & Upstream site & $238[216,247](284)$ & $238[212,298](202)^{*}$ \\
& Midstream site & $149[141,164](324)$ & $166[152,190](234)^{*}$ \\
& Downstream site & $166[156,180](300)$ & $168[150,186](184)$ \\
\hline \multirow{2}{*}{$\mathrm{NH}_{4}^{+}\left(\mu \mathrm{g} \mathrm{N}^{-1}\right)$} & Upstream site & $10.8[8.2,14.4](281)$ & $9.2[6.8,10.8](170)^{*}$ \\
& Midstream site & $10.0[7.2,13.7](344)$ & $8.7[6.6,10.8](229)^{*}$ \\
& Downstream site & $9.2[6.8,12.7](310)$ & $8.0[6.3,10.4](147)^{*}$ \\
\hline
\end{tabular}
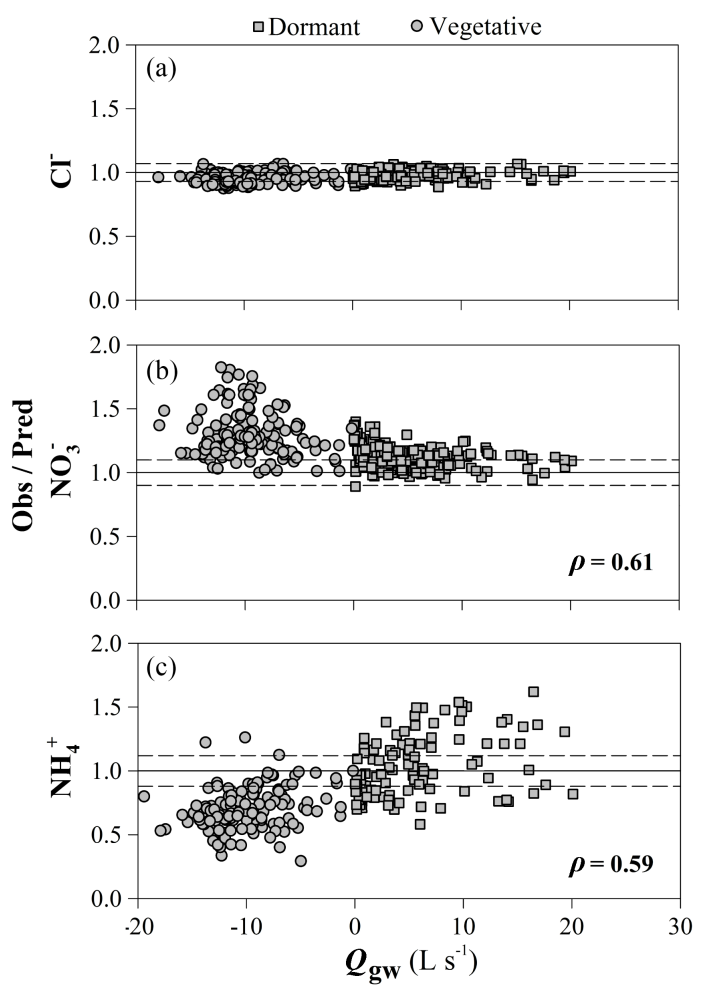

Figure 5. Relationship between mean daily net groundwater inputs $\left(Q_{\mathrm{gw}}\right)$ and the ratio between stream concentrations observed at the bottom of the valley reach (downstream site) and those predicted from hydrological mixing for (a) chloride, (b) nitrate and (c) ammonium. Data are shown separately for the vegetative (circles) and dormant (squares) period. The Spearman coefficient is shown in each case. The solid line indicates no differences between observed and predicted concentrations, and the dashed lines indicate the uncertainty associated with the zero line as explained in the material and methods section. species can obtain between 30 and $90 \%$ of their water requirements from the surface soil (0-50 cm depth) (Brooks et al., 2009; Sánchez-Pérez et al., 2008; Snyder and Williams, 2000). On a seasonal basis, riparian ET influenced the temporal pattern of both stream and groundwater hydrology because $\Delta Q_{\text {lost }}$ was negatively related to $Q_{\mathrm{gw}}$, and positively related to mean daily $h_{\mathrm{gw}}$. In agreement, previous studies have reported that riparian water demand $\left(0.5-5 \mathrm{~mm} \mathrm{day}^{-1}\right)$ can severely drop the groundwater table (Sabater and Bernal, 2011; Schilling, 2007) and decrease the amount of groundwater entering streams by 30-100\% (Dahm et al., 2002; Folch and Ferrer, 2015; Kellogg et al., 2008). On an annual basis, riparian transpiration at the study site $(350$ $450 \mathrm{~mm} \mathrm{yr}^{-1}$ ) was small compared to published values of ET for other riparian forests worldwide (400-1300 $\mathrm{mm} \mathrm{yr}^{-1}$ ) (Scott et al., 2008) as well as compared to oak and beech upland forests (600-900 $\mathrm{mm} \mathrm{yr}^{-1}$ ) (Àvila et al., 1996; Llorens and Domingo, 2007). These low ET values could partially be explained by the low radiation reaching the riparian canopy $\left(36 \pm 18 \mathrm{~W} \mathrm{~m}^{-2} \mathrm{day}^{-1}\right)$ compared to the radiation reaching non-shaded areas of the catchment $\left(270 \pm 70 \mathrm{~W} \mathrm{~m}^{-2}\right.$ day $^{-1}$; unpublished data), a phenomenon already described in the literature (Aguilar et al., 2010). The relatively low ET values, together with the fact that the riparian forest occupied a small area of the catchment $(6 \%)$, resulted in a minimal contribution $(4.5 \%)$ of riparian transpiration to the annual water budget for this catchment. This estimate is similar to values reported for tropical (Cadol et al., 2012), temperate (e.g., Petrone et al., 2007; Salemi et al., 2012), and Mediterranean (e.g., Bernal and Sabater, 2012; Folch and Ferrer, 2015; Wine and Zou, 2012) systems, while being several folds lower than values reported for semiarid and dry land regions (Contreras et al., 2011; Dahm et al., 2002; Doble et al., 2006) (Fig. 6). Together, these results suggest that the relative contribution of riparian ET to catchment water depletion across biomes could be explained by differences in water availability (Fig. 6 and Table S2). Therefore, the po- 


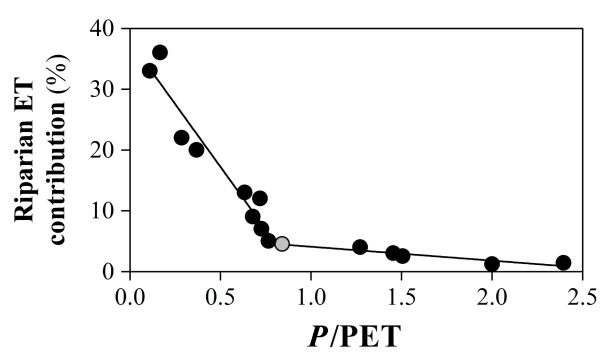

Figure 6. Relationship between the relative contribution of riparian evapotranspiration (ET) to annual catchment water depletion and the ratio between annual precipitation and potential evapotranspiration $(P / \mathrm{PET})$ for a set of catchments worldwide $(n=15)$. Total water output fluxes from the catchment are stream discharge, catchment evapotranspiration, riparian evapotranspiration, and anthropogenic extraction (if applies). The Font del Regàs catchment (present study) is indicated with a gray circle. More information and references of the study sites are in the Supplement (Table S2).

tential of riparian forests to control catchment and stream hydrology at both large and fine timescales could dramatically increase in regions experiencing some degree of water limitation $(P / \mathrm{PET}<1)$.

In concordance with our expectations, the influence of riparian ET on stream hydrology varied along the stream continuum, likely due to changes in the balance between water availability and water demand. At the upstream site, maxima $Q_{\text {lost }}$ values (7\% of mean daily $Q$ ) were similar to values reported for systems with no water limitation (Bond et al., 2002; Cadol et al., 2012), while maxima $Q_{\text {lost }}$ values for the downstream site ( $19 \%$ of mean daily $Q$ ) were close to those reported for water-limited systems (Lundquist and Cayan, 2002). Stream hydrological retention occurred mostly at the valley reach, where riparian forest was well developed, thus suggesting higher riparian water requirements at the valley bottom (Bernal and Sabater, 2012; Covino and McGlynn, 2007; Montreuil et al., 2011). Yet, the increase in stream hydrological retention along the stream could be favored by additional factors such as longitudinal changes in channel geomorphology, riparian topography, upland-riparian hydrological connectivity, or the hydraulic gradient between the riparian aquifer and the stream (Covino et al., 2010; Detty and McGuire, 2010; Duval and Hill, 2006; Jencso et al., 2009; Vidon and Hill, 2004). Overall, our results suggest that, despite being insignificant for catchment water budgets, riparian ET exerted a strong influence on diel and seasonal patterns of riparian groundwater table and stream discharge likely due to the proximity and strong hydrological connectivity between these two water bodies.

\subsection{Influence of stream hydrological retention on stream $\mathbf{N}$ concentrations}

In contrast to our expectations, the prevalence of stream hydrological retention during the vegetative period at the valley reach was accompanied by an increase of stream $\mathrm{NO}_{3}^{-}$ concentrations (Obs: Pred $>1)$. This result suggests $\mathrm{NO}_{3}^{-}$release within the stream channel, which conflicts with previous studies reporting $\mathrm{NO}_{3}^{-}$uptake at the stream-riparian edge in net losing reaches (Bernal and Sabater, 2012; Duval and Hill, 2007; Rassam et al., 2006). Biological $\mathrm{NO}_{3}^{-}$ uptake at the stream-riparian edge typically occurs when a large volume of water flows directly or remains a long time in anoxic zones within the rhizosphere and/or the organicrich soils flanking the stream channel (Duval and Hill, 2007; Schade et al., 2005). At Font del Regàs, however, there was a permanent disconnection between riparian groundwater and surface soil layers, which may have limited the occurrence of microbial denitrification and plant $\mathrm{NO}_{3}^{-}$uptake during periods of stream hydrological retention (Burt et al., 2002; Hefting et al., 2004).

Furthermore, in-stream $\mathrm{NO}_{3}^{-}$release was accompanied by $\mathrm{NH}_{4}^{+}$uptake (Obs: Pred $\left.<1\right)$, suggesting that in-stream nitrification prevailed at the valley reach. Previous studies have reported sustained in-stream nitrification in well-oxygenated, slow water flowing, hyporheic zones (Dent et al., 2007; Jones et al., 1995; Triska et al., 1990), and also when stored leaf packs are rich in organic $\mathrm{N}$ and labile carbon (Mineau et al., 2011; Starry et al., 2005). The two aforementioned explanations suit Font del Regàs because the valley reach had inputs of N-rich leaf litter (Bernal et al., 2015) and a well-oxygenated hyporheic zone $\left(\sim 7 \mathrm{mg} \mathrm{O}_{2} \mathrm{~L}^{-1}\right.$; unpublished data) during periods of stream hydrological retention. Moreover, in-stream nitrification in summer could be stimulated by warm water temperatures (Laursen and Seitzinger, 2004) and both low discharge $\left(<30 \mathrm{~L} \mathrm{~s}^{-1}\right)$ and stream depth $(<15 \mathrm{~cm})$, which ultimately could favor the contact between nutrients and the microbial communities. Alternatively, differences in $\mathrm{NO}_{3}^{-}$and $\mathrm{NH}_{4}^{+}$concentrations between the headwater and the valley reach could be explained by hydrological mixing with unaccounted water sources, such as deep groundwater (Clément et al., 2003) or riparian N-rich soils (Hill, 2011). However, these two explanations were discarded because small mismatches between observed and predicted $\mathrm{Cl}^{-}$concentrations indicate that the mixing model included the main water sources contributing to stream discharge. Together, these results suggest that processes occurring within the stream surface channel or in the hyporheic zone can overwhelm those occurring at the stream-riparian edge, especially during periods of high hydrological retention.

During the dormant period, when the two reaches gained water from the riparian groundwater, Obs: Pred ratios at the downstream site were $\geq 1$ for both $\mathrm{NO}_{3}^{-}$and $\mathrm{NH}_{4}^{+}$. 
This finding does not support previous studies showing that riparian zones increase their $\mathrm{N}$ buffer capacity from headwaters to valley bottom (Montreuil et al., 2011; Rassam et al., 2006). For $\mathrm{NO}_{3}^{-}$, this pattern could be explained by limited riparian denitrification, given that (i) $\mathrm{NO}_{3}^{-}$ availability was low in groundwater arriving from uplands ( $<1 \mathrm{mg} \mathrm{L}^{-1}$; unpublished data), and (ii) groundwater and organic-rich soils were hydrologically disconnected even during the dormant period. Additionally, high rates of $\mathrm{N}$ mineralization and nitrification in the riparian soil during winter $\left(0.84 \pm 0.23 \mathrm{mg} \mathrm{N} \mathrm{kg}^{-1} \mathrm{day}^{-1}\right)$ could promote $\mathrm{N}$ export from the riparian zone to the stream at the valley reach (Lupon et al., 2016).

The influence of in-stream $\mathrm{N}$ cycling on $\mathrm{N}$ export ultimately depends on water fluxes and the hydrological exchange between riparian and stream ecosystems, which vary over the year. During the vegetative period, $\mathrm{NO}_{3}^{-}$fluxes entering and exiting the valley reach were similar (median $=8.8$ and $8.9 \mathrm{mg} \mathrm{N} \mathrm{s}^{-1}$, respectively) mostly because the increase in stream $\mathrm{NO}_{3}^{-}$concentration at the valley reach was counterbalanced by the loss of water from the stream towards the riparian zone induced by riparian ET. Otherwise, $\mathrm{NO}_{3}^{-}$export to downstream ecosystems would have been $15 \%$ higher. Similarly, during the dormant period, there were no differences between input and output $\mathrm{NO}_{3}^{-}$fluxes at the valley reach, but in this case discharge and $\mathrm{NO}_{3}^{-}$ concentrations were similar between the top and the bottom of the reach $\left(Q=110\right.$ vs. $113 \mathrm{~L} \mathrm{~s}^{-1}$ and $\mathrm{NO}_{3}^{-}=0.166$ vs. $0.168 \mathrm{mg} \mathrm{N}^{-1}$ ). These back-of-the-envelope calculations highlight that riparian ET and stream-riparian hydrological exchange can substantially influence stream $\mathrm{N}$ fluxes during some time windows of the year, despite it having small implications for $\mathrm{N}$ fluxes at annual scale.

\section{Conclusions}

Our study adds to the growing evidence demonstrating that riparian ET is a key process for understanding temporal patterns of stream discharge and hydrological processes at the stream-riparian edge in small forested catchments, despite its modest contribution to annual water budgets (Folch and Ferrer, 2015; Medici et al., 2008). Riparian ET strongly controlled the temporal pattern of net groundwater inputs and stream discharge across daily and seasonal scales. From a network perspective, the influence of riparian ET on stream hydrology increased along the stream continuum and promoted stream hydrological retention at the valley reach. In contrast to previous studies, high stream hydrological retention was accompanied by increases in nitrate concentrations, likely due to in-stream nitrification enhanced by low stream flows, large stocks of $\mathrm{N}$-rich leaf litter, warm conditions, and well-oxygenated hyporheic zones. In addition, we found no clear evidence of riparian effects on stream $\mathrm{N}$ dynamics during the dormant period. Our findings highlight that riparian
ET can regulate the spatiotemporal pattern of stream-water fluxes in Mediterranean regions and question the $\mathrm{N}$ buffering capacity of Mediterranean riparian zones at catchment scale.

\section{Data availability}

The data sets used in this paper can be obtained from the authors upon request.

\section{The Supplement related to this article is available online at doi:10.5194/hess-20-3831-2016-supplement.}

Author contributions. Anna Lupon, Susana Bernal, and Francesc Sabater designed the experiment. Anna Lupon, Susana Bernal, and Sílvia Poblador carried them out. Anna Lupon performed all laboratory analysis. Anna Lupon analyzed the data set and prepared the manuscript with contributions from $\mathrm{Su}$ sana Bernal, Sílvia Poblador, Eugènia Martí, and Francesc Sabater.

Acknowledgements. We are thankful to Ada Pastor and Lídia Cañas for their invaluable assistance in the field, and to Dani Nadal for providing data on riparian tree evapotranspiration. Financial supported was provided by the Spanish Government through the projects MONTES-Consolider (CSD2008-00040MONTES), MEDFORESTREAM (CGL2011-30590), and MEDSOUL (CGL2014-59977-C3-2). Anna Lupon was supported by a FPU PhD fellowship from the Spanish Ministry of Education and Science (AP-2009-3711) and the MEDSOUL project. Susana Bernal work was funded by the Spanish Research Council (JAE-DOC027), the Spanish CICT (Juan de la Cierva contract JCI-2008-177), European Social Funds (FSE), and the NICUS (CGL-2014-55234-JIN) project. Sílvia Poblador was supported by a FPI PhD fellowship from the Spanish Ministry of Economy and Competitiveness (BES-2012-054572). We also thank site cooperators, including Vichy Catalan and the Catalan Water Agency (ACA) for permission to sample at the Font del Regàs catchment.

Edited by: C. Stamm

Reviewed by: two anonymous referees

\section{References}

Aguilar, C., Herrero, J., and Polo, M. J.: Topographic effects on solar radiation distribution in mountainous watersheds and their influence on reference evapotranspiration estimates at watershed scale, Hydrol. Earth Syst. Sci., 14, 2479-2494, doi:10.5194/hess14-2479-2010, 2010.

Àvila, A. and Rodà, F.: Changes in atmospheric deposition and streamwater chemistry over 25 years in undisturbed catchments in a Mediterranean mountain environment, Sci. Total Environ., 434, 18-27, 2012. 
Àvila, A., Neal, C., and Terradas, J.: Climate change implications for streamflow and streamwater, J. Hydrol., 177, 99-116, 1996.

Baethgen, W. and Alley, M.: A manual colorimetric procedure for ammonium nitrogen in soil and plant Kjeldahl digests, Commun. Soil Sci. Plant Anal., 20, 961-969, 1989.

Bernal, S. and Sabater, F.: Changes in discharge and solute dynamics between hillslope and valley-bottom intermittent streams, Hydrol. Earth Syst. Sci., 16, 1595-1605, doi:10.5194/hess-16-15952012, 2012.

Bernal, S., Lupon, A., Ribot, M., Sabater, F., and Martí, E.: Riparian and in-stream controls on nutrient concentrations and fluxes in a headwater forested stream, Biogeosciences, 12, 1941-1954, doi:10.5194/bg-12-1941-2015, 2015.

Bond, B. J., Jones, J. A., Moore, G., Phillips, N., Post, D., and McDonnell, J. J.: The zone of vegetation influence on baseflow revealed by diel patterns of streamflow and vegetation water use in a headwater basin, Hydrol. Process., 16, 1671-1677, 2002.

Brooks, R. J., Barnard, H. R., Coulombe, R., and McDonnell, J. J.: Ecohydrologic separation of water between trees and streams in a Mediterranean climate, Nat. Geosci., 3, 100-104, 2009.

Burt, T. P., Pinay, G., Matheson, F. E., Haycock, N. E., Butturini, A., Clément, J.-C., Danielescu, S., Dowrick, D. J., Hefting, M. M., Hillbricht-Ilkowska, A., and Maître, V.: Water table fluctuations in the riparian zone: Comparative results from a pan-European experiment, J. Hydrol., 265, 129-148, 2002.

Cadol, D., Kampf, S., and Wohl, E.: Effects of evapotranspiration on baseflow in a tropical headwater catchment, J. Hydrol., 462463, 4-14, 2012.

Clément, J.-C., Aquilina, L., Bour, O., Plaine, K., Burt, T. P., and Pinay, G.: Hydrological flowpaths and nitrate removal rates within a riparian floodplain along a fourth-order stream in Brittany (France), Hydrol. Process., 17, 1177-1195, 2003.

Contreras, S., Jobbágy, E. G., Villagra, P. E., Nosetto, M. D., and Puigdefábregas, J.: Remote sensing estimates of supplementary water consumption by arid ecosystems of central Argentina, J. Hydrol., 397, 10-22, 2011.

Covino, T. P. and McGlynn, B. L.: Stream gains and losses across a mountain-to-valley transition: Impacts on watershed hydrology and stream water chemistry, Water Resour. Res., 43, W10431, doi:10.1029/2006WR005544, 2007.

Covino, T. P., McGlynn, B., and Baker, M. A.: Separating physical and biological nutrient retention and quantifying uptake kinetics from ambient to saturation in successive mountain stream reaches, J. Geophys. Res., 115, G04010, doi:10.1029/2009JG001263, 2010.

Dahm, C. N., Cleverly, J. R., Allred, C. E., J., Thibault, J. R., McDonnell, D. E., and Gilroy, D. J.: Evapotranspiration at the land/water interface in a semi-arid drainage basin, Freshwater Biol., 47, 831-844, 2002.

Dent, C. L., Grimm, N. B., Martí, E., Edmonds, J. W., Henry, J. C., and Welter, J. R.: Variability in surface-subsurface hydrologic interactions and implications for nutrient retention in an arid-land stream, J. Geophys. Res., 112, G04004, doi:10.1029/2007JG000467, 2007.

Detty, J. M. and McGuire, K. J.: Topographic controls on shallow groundwater dynamics: implications of hydrologic connectivity between hillslopes and riparian zones in a till mantled catchment, Hydrol. Process., 24, 2222-2236, 2010.
Doble, R., Simmons, C., Jolly, I., and Walker, G.: Spatial relationships between vegetation cover and irrigation-induced groundwater discharge on a semi-arid floodplain, Australia, J. Hydrol., 329, 75-97, 2006.

Duval, T. P. and Hill, A. R.: Influence of stream bank seepage during low-flow conditions on riparian zone hydrology, Water Resour. Res., 42, W10425, doi:10.1029/2006WR004861, 2006.

Duval, T. P. and Hill, A. R.: Influence of base flow stream bank seepage on riparian zone nitrogen biogeochemistry, Biogeochemistry, 85, 185-199, 2007.

Folch, A. and Ferrer, N.: The impact of poplar tree plantations for biomass production on the aquifer water budget and base flow in a Mediterranean basin, Sci. Total Environ., 524-525, 213-224, doi:10.1016/j.scitotenv.2015.03.123, 2015.

Gordon, N. D., McMahon, T. A., and Finlayson, B. L.: Stream hydrology: an introduction forecologists, P. Hall, New Jersey, 1992.

Granier, A.:Une nouvelle méthode pour la mesure du flux de sève brute dans le tronc des arbres, in: Annales des Sciences Forestieres, 42, EDP Sciences, 193-200, 1985.

Gribovszki, Z., Szilágyi, J., and Kalicz, P.: Diurnal fluctuations in shallow groundwater levels and streamflow rates and their interpretation - A review, J. Hydrol., 385, 371-383, 2010.

Hefting, M. M., Clément, J.-C., Dowrick, D. J., Cosandey, A. C., Bernal, S., Cimpian, C., Tatur, A., Burt, T. P., and Pinay, G.: Water table elevation controls on soil nitrogen cycling in riparian wetlands along a European climatic gradient, Biogeochemistry, 67, 113-134, 2004.

Hill, A. R.: Nitrate removal in stream riparian zones, J. Environ. Qual., 25, 743-755, 1996.

Hill, A. R.: Buried organic-rich horizons: their role as nitrogen sources in stream riparian zones, Biogeochemistry, 104, 347363, 2011.

Institut Cartografic de Catalunya: Orthophotomap of Catalunya $1: 25000$, Generalitat de Catalunya, Departament de Política Territorial i Obres, Barcelona, Spain, 2010.

Jencso, K. G., McGlynn, B. L., Gooseff, M. N., Wondzell, S. M., Bencala, K. E., and Marshall, L. A.: Hydrologic connectivity between landscapes and streams: Transferring reach- and plot-scale understanding to the catchment scale, Water Resour. Res., 45, W04428, doi:10.1029/2008WR007225, 2009.

Jones, J. B., Fisher, S. G., and Grimm, N. B.: Nitrification in the hyporheic zone of a desert stream ecosystem, J. N. Am. Benthol. Soc., 14, 249-258, 1995.

Keeney, D. R. and Nelson, D. W.: Nitrogen-inorganic forms, in Methods of soil a nalysis. Part 2., edited by: Page, A. L., Agronomy Monography 9, ASA and SSSA, Madison, WI, 643-698, 1982.

Kellogg, D. Q., Gold, A. J., Groffman, P. M., Stolt, M. H. and Addy, K.: Riparian groundwater flow patterns using flownet analysis: evapotranspiration-induced upwelling and implications for $\mathrm{N}$ removal, J. Am. Water Resour. Assoc., 44, 1024-1034, 2008.

Kirchner, J. W., Feng, X. H., and Neal, C.: Catchment-scale advection and dispersion as a mechanism for fractal scaling in stream tracer concentrations, J. Hydrol., 254, 82-101, 2001.

Laursen, A. E. and Seitzinger, S. P.: Diurnal patterns of denitrification, oxygen consumption and nitrous oxide production in rivers measured at the whole-reach scale, Freshwater Biol., 49, 14481458, doi:10.1111/j.1365-2427.2004.01280.x, 2004. 
Llorens, P. and Domingo, F.: Rainfall partitioning by vegetation under Mediterranean conditions. A review of studies in Europe, J. Hydrol., 335, 37-54, 2007.

Lundquist, J. D. and Cayan, D. R.: Seasonal and spatial patterns in diurnal cycles in streamflow in the western United States, J. Hydrometeorol., 3, 591-603, 2002.

Lupon, A., Sabater, F., Miñarro, A., and Bernal, S. Contribution of pulses of soil nitrogen mineralization and nitrification to soil nitrogen availability in three Mediterranean forests, Eur. J. Soil Sci., 67, 303-313, 2016.

Martí, E., Grimm, N. B., and Fisher, S. G.: Pre- and post-flood retention efficiency of nitrogen in a Sonoran Desert stream, J. N. Am. Benthol. Soc., 16, 805-819, 1997.

Mayer, P. M., Reynolds, S. K., McCutchen, M. D., and Canfield, T. J.: Meta-analysis of nitrogen removal in riparian buffers, J. Environ. Qual., 36, 1172-1180, 2007.

McClain, M. E., Boyer, E. W., Dent, C. L., Gergel, S. E., Grimm, N. B., Groffman, P. M., Hart, S. C., Harvey, J. W., Johnston, C. A., Mayorga, E., McDowell, W. H., and Pinay, G.: Biogeochemical hot spots and Hot moments at the interface of terrestrial and aquatic ecosystems, Ecosystems, 6, 301-312, 2003.

Medici, C., Butturini, A., Bernal, S., Sabater, F., and Franc, F.: Modelling the non-linear hydrological behaviour of a small Mediterranean forested catchment, Hydrol. Process., 28, 3814-3828, 2008

Mineau, M. M., Baxter, C. V., and Marcarelli, A. M.: A non-native riparian tree (Elaeagnus angustifolia) changes nutrient dynamics in streams, Ecosystems, 14, 353-365, 2011.

Montreuil, O., Cudennec, C., and Merot, P.: Contrasting behaviour of two riparian wetlands in relation to their location in the hydrographic network, J. Hydrol., 406, 39-53, 2011.

Nadal-Sala, D., Sabaté, S., Sánchez-Costa, E., Boumghar, A., and Gracia, C. A.: Different responses to water availability and evaporative demand of four co-occurring riparian tree species in NE Iberian Peninsula. Temporal and spatial sap flow patterns, Acta Hortic., 991, 215-222, 2013.

Ocampo, C. J., Sivapalan, M., and Oldham, C.: Hydrological connectivity of upland-riparian zones in agricultural catchments: Implications for runoff generation and nitrate transport, J. Hydrol., 331, 643-658, 2006.

Pert, P. L., Butler, J. R. A., Brodie, J. E., Bruce, C., Honzák, M., Metcalfe, D., Mitchell, D., and Wong, G.: A catchment-based approach to mapping hydrological ecosystem services using riparian habitat: A case study from the Wet Tropics, Australia, Ecol. Complex., 7, 378-388, 2010.

Petrone, K., Buffam, I., and Laudon, H.: Hydrologic and biotic control of nitrogen export during snowmelt: A combined conservative and reactive tracer approach, Water Resour. Res., 43, W06420, doi:10.1029/2006WR005286, 2007.

Pinay, G., Black, V. J., Planty-Tabacchi, A.-M., Gumiero, B., and Décamps, H.: Geomorphic control of denitrification in large river floodplain soils, Biogeochemistry, 50, 163-182, 2000.

Ranalli, A. J. and Macalady, D. L.: The importance of the riparian zone and in-stream processes in nitrate attenuation in undisturbed and agricultural watersheds-A review of the scientific literature, J. Hydrol., 389, 406-415, 2010.

Rassam, D. W., Fellows, C. S., De Hayr, R., Hunter, H., and Bloesch, P.: The hydrology of riparian buffer zones; two case studies in an ephemeral and a perennial stream, J. Hydrol., 325, 308-324, 2006.

R Core Team: R: A language and environment for statistical computing, R Foundation for Statistical Computing, Vienna, Austria, 2012.

Roberts, J.: Forest transpiration: a conservative hydrological process, J. Hydrol., 66, 133-141, 1983.

Sabater, F. and Bernal, S.: Keeping healthy riparian and aquatic ecosystems in the Mediterranean: challenges and solutions through riparian forest management, in: Water for Forests and People in the Mediterrane, edited by: Boirot, M., Gracia, Y., and Palahí, C., European Forest Institut, Joensuu, Finland, 151-155, 2011.

Salemi, L. F., Groppo, J. D., Trevisan, R., Marcos de Moraes, J., de Paula Lima, W., and Martinelli, L. A.: Riparian vegetation and water yield: A synthesis, J. Hydrol., 454-455, 195-202, 2012.

Sánchez-Pérez, J. M., Lucot, E., Bariac, T., and Trémolières, M.: Water uptake by trees in a riparian hardwood forest (Rhine floodplain, France), Hydrol. Process., 22, 366-375, 2008.

Savé, R., Castell, C., and Terradas, J.: Gas exchange and water relations, in: Ecology of Mediterranean evergreen oak forests, Springer, Berlin, Heidelberg, Germany, 135-147, 1999.

Schade, J. D., Welter, J. R., Martí, E., and Grimm, N. B.: Hydrologic exchange and $\mathrm{N}$ uptake by riparian vegetation in an arid-land stream Hydrologic exchange and $\mathrm{N}$ uptake by riparian vegetation in an arid-land stream, J. N. Am. Benthol. Soc., 24, 19-28, 2005.

Schilling, K. E.: Water table fluctuations under three riparian land covers, Iowa (USA), Hydrol. Process., 21, 2415-2424, 2007.

Scott, R. L., Cable, W. L., Huxman, T. E., Nagler, P. L., Hernandez, M., and Goodrich, D.: Multiyear riparian evapotranspiration and groundwater use for a semiarid watershed, J. Arid Environ., 72, 1232-1246, 2008.

Snyder, K. A. and Williams, D. G.: Water sources used by riparian trees varies among stream types on the San Pedro River, Arizona, Agr. Forest Meteorol., 105, 227-240, 2000.

Starry, O. S., Valett, H. M., and Schreiber, M. E.: Nitrification rates in a headwater stream: influences of seasonal variation in $\mathrm{C}$ and N supply, J. N. Am. Benthol. Soc., 24, 753-768, 2005.

Technicon: Technicon Instrument System, Technicon Method Guide, Technicon, Tarrytown, NY, 1976.

Triska, F. J., Duff, J. H., and Avanzino, R. J.: Patterns of hydrological exchange and nutrient transformation in the hyporheic zone of a gravel-bottom stream: examining terrestrial - aquatic linkages, Freshwater Biol., 29, 259-274, 1993.

Vidon, P., Allan, C. J., Burns, D., Duval, T. P., Gurwick, N., Inamdar, S., Lowrance, R., Okay, J., Scott, D., and Sebestyen, S.: Hot spots and hot moments in riparian zones: Potential for improved water quality management, J. Am. Water Resour. Assoc., 46, 278-298, 2010.

Vidon, P. G. F. and Hill, A. R.: Landscape controls on the hydrology of stream riparian zones, J. Hydrol., 292, 210-228, 2004.

Wine, M. L. and Zou, C. B.: Long-term streamflow relations with riparian gallery forest expansion into tallgrass prairie in the Southern Great Plains, USA, Forest Ecol. Manage., 266, 170-179, 2012.

Zar, J. H.: Biostatistical analysis, 5th Edn., Prentice-Hall/Pearson, Upper Saddle River, NJ, 2010. 